\title{
To eradicate or not to eradicate? Recommendations on Prosopis juliflora management in Afar, Ethiopia, from an interdisciplinary perspective
}

\author{
John Ilukor*, Simone Rettberg, Anna Treydte and Regina Birner
}

\begin{abstract}
As one of the most invasive species of arid and semi-arid areas of East Africa, Prosopis juliflora has become a major threat to livelihoods of the Afar pastoral people and to the fragile ecosystems they live in. This paper comprises results from a multidisciplinary study on the spread of $P$. juliflora as an invasive species in the Ethiopian Afar Region and provides suggestions on its management and control. The study investigated spread of $P$. juliflora, ecological aspects (shifts in vegetation biomass and soil properties) and socio-economic aspects (livelihood impacts, management activities and potential) of P. juliflora invasion. Ecological methods included conducting destructive harvesting on vegetation; soil analyses and a soil seed bank assessment as well as using allometric equations to estimate the biomass and carbon contents of P. juliflora. Socio-economic data was collected based a survey of 490 pastoral households including 213 from Amibara, 177 from Gewane and 100 from Awash Fentale. Stated and revealed preference methods (RPM) were used because impacts of $P$. juliflora are both tangible and intangible. The study found that wetlands (flood plains in the Awash Basin) are highly susceptible to Prosopis invasion relative to drylands. Clearing invaded land and continuously using it for crop farming would reduce the invasion. The study also found that the available nitrogen, phosphorus and organic carbon in the soil were high in highly invaded areas compared to less or non-invaded sites. However, the basal cover of native herbaceous vegetation and native tree diversity were found to be much reduced under high $P$. juliflora-invaded areas. Results from economic analyses also reveal that the benefits of the $P$. juliflora invasion in the Afar region are higher than the costs. However, some aspects such as increased risk of erosion, the impact of $P$. juliflora on the water table and long-term ecological changes were not examined, thus making the total economic valuation incomplete. Nonetheless, the study has captured most aspects of $P$. juliflora invasion in the Afar region and concludes that sustainable management and control of $P$. juliflora in the Afar region may be a better solution than eradication.
\end{abstract}

Keywords: Prosopis juliflora, pastoralism, costs and benefits, invasive species

\section{Background to the study and findings}

The spread of invasive plant species within the arid and semiarid lowlands of Northeast Ethiopia is an increasing threat for pastoral livelihoods and ecosystems. One of the most invasive species is Prosopis juliflora, an evergreen, fast-growing tree or shrub, native to South and Central America (Mwangi and Swallow 2008). The Ethiopian National Biodiversity Strategy and Action

* Correspondence: john.ilukor@gmail.com

Makerere University College of Agricultural and Environmental Sciences, Kampala, Uganda
Plan (MoARD 2005) considers it to be one of the top invasive species countrywide, next to Parthenium weed (Parthenium hysterophorus), water hyacinth (Eichhornia crassipes) and Lantana weed (Lantana camara). P. juliflora was first introduced to the Afar region by the Ethiopian government in the late 1970s and early 1980s to combat desertification, and by 2006 , approximately 700,000 ha of land had been taken over by P. juliflora, out of which more than $70 \%$ is located in the Afar region (Admasu 2008; Ryan 2011). 
$P$. juliflora has been reported to offer significant ecosystem and livelihood services such as microclimate regulation, improvement of soil fertility, reclaiming saline and alkaline soils and income and livelihood diversification (Bhojvaid and Timmer 1998; Berhanu and Tesfaye 2006). This is particularly important for the arid lands of Afar, $50 \%$ of which is exposed soil, sand and rock (ANRS 2010). Along the Awash River flood plains, dense woodland and swamps have been reclaimed for irrigation (ANRS 2010). Kahi et al. (2009) found that soils under P. juliflora had higher organic carbon and total nitrogen than soils in the open areas. Although soils under Acacia spp. trees had higher organic carbon and total nitrogen than soils under P. juliflora (Kahi et al. 2009), Acacia spp. trees are not capable of surviving in the Afar region. P. juliflora's high coppicing ability and deep roots enable them to survive in drylands where they provide a number of benefits including alternative energy sources (Ayanu et al. 2015). The pods from $P$. juliflora can also be a source of nutritious human food (Choge et al. 2007) as well as a nutritious, less costly feed ingredient for livestock (Sawal et al. 2004; Stein et al. 2005; Chaturvedi and Sahoo 2013). Both crushed and uncrushed $P$. juliflora pods can be fed to livestock (Berhanu and Tesfaye 2006) and in pastoral areas like Afar with acute shortage of fresh water, $P$. juliflora has been seen as an alternative source of feed because it tolerates adverse arid conditions (Mahgoub et al. 2005).

Recent studies by Ayanu et al. (2015) and Haregeweyn et al. (2013) have shown that the P. juliflora invasion rate is increasing rapidly, suppressing indigenous plants, while negatively affecting human health as well as livestock production. $P$. juliflora creates an environment conducive for mosquito breeding, limits access to watering points and grazing lands and offers cover for wild predatory animals such as lions (Panthera leo) (Pasiecznik et al. 2001; Mehari 2015). Attempts to access these areas have resulted in injuries to both animals and humans (Mwangi and Swallow 2008). Afar pastoralists who call it the "Devil Tree" and the "AIDS" to the animals want it to be eradicated. Policy-makers and development partners are faced with the dilemma of whether to completely eradicate $P$. juliflora or manage this species intensely. However, the measures that have been adopted in the Afar region have thus far not been able to manage and control this species' rapid spread and it appears that the negative impacts exceed the positive impacts, especially for pastoralists, the main inhabitants of Afar Region in Ethiopia.

Against this background, the German Ministry for Economic Cooperation and GIZ (Gesellschaft für Internationale Zusammenarbeit) decided to fund an interdisciplinary research study on "Woody Encroachment in the Afar Region, Ethiopia: Impact Assessment of Prosopis Invasion and Participative Management Approaches". In 2013 to 14, the study was implemented by Ethiopian-German research teams led by the University of Hohenheim (ecology, economy) and the University of Bonn (sociology, remote sensing) in association with the Mekelle University, Samara University and Ethiopian Environment and Forestry Research Institute. The project's objective was to assess the extent and impact of land degradation through $P$. juliflora in the Afar Region, and to estimate the costs and benefits of $P$. juliflora invasion. It was decided to focus on an empirical case study within one of the most heavily invaded areas in Afar, the Middle Awash Basin, the seasonally inundated floodplains of Gewane and of Amibara Woreda, where P. juliflora has spread rapidly over the last decades (Müller-Mahn and Rettberg 2012).

\section{Results}

\section{The invasion and spread of $P$. juliflora}

The quantitative assessment of $P$. juliflora spread within the Baadu area (Gewane Woreda) was based on a comparison of Cloud-free Landsat ETM (30-m resolution) and ASTER (15-m resolution) satellite images taken during the dry seasons (October-March) of 2000, 2005, 2010, and 2013. The results revealed that the rate of $P$. juliflora invasion over the past two decades is tremendously high, and within five years (2000 to 2005), the total area of wetlands invaded by $P$. juliflora increased from 3,600 to 8,000 ha (i.e. from $8 \%$ to $18 \%$ ). About $30 \%$ of the wetlands were invaded in 2010 - which is equivalent to a total area over 13,000 ha - and by the end of 2013, almost $40 \%$ of the wetlands in Baadu were invaded. This implies a 10\% increment over a period of three years when compared with 2010 (Ayanu et al. 2015). The area of agricultural land invaded by $P$. juliflora was only 2 ha $(<1 \%)$ even though it increased to 76 ha $(4 \%)$ in the year 2005. By 2010, the total agricultural land invaded by $P$. juliflora had increased to 166 ha, but this amounted only to $2 \%$ of the total agricultural land. The reduction in the percentage of the invaded agricultural land is attributed to increased cultivated area compared with previous years, and overall increase in cultivated land could also be associated with $P$. juliflora, which is known to reclaim saline and alkaline soils, which might have made the soils available for cultivation. By the end of 2013, 4\% (327 ha) of total area of agricultural land was invaded, and this is associated with the fact that investors abandoned their farmland, allowing $P$. juliflora to continue invading. Only $1 \%$ of the total drylands were invaded, and this is probably because animals do not graze in these areas and the soils have less moisture available to facilitate $P$. juliflora invasion (Treydte et al. 2014; Ayanu et al. 2015).

\section{Ecological consequences of $P$. juliflora invasion}

The acacia trees are not capable of surviving in Afar region and continue to provide fuel wood, charcoal and regulate the microclimate compared to prosopis. This 
trend was similar for above and below ground biomass (see Figure 1).

The study also found that the available phosphorus and organic carbon in the soil were more than twice as high at highly and intermediate infested sites compared to low and non-infested sites. The nitrogen level and the moisture content in soils of highly infested areas were $23 \%$ and $11 \%$ to $13 \%$, respectively. These levels are more than twice as high compared to those of low or noninfested areas. However, species diversity and richness of the woody vegetation in Gewane and Amibara were found to be very low (four to five species) even in areas without $P$. juliflora. In areas of high and medium $P$. juliflora invasion, the individuals or plants of other species were not available or recorded (see Table 1). Therefore, $P$. juliflora might reduce this diversity further. The basal cover of native herbaceous vegetation was found to be much reduced under high $P$. juliflora infestation.

However, the seed bank of soils under high $P$. juliflora infestation showed up to 14 different species available when grown in the greenhouse. Hence, there is potential for $P$. juliflora-infested soils that, once cleared, native vegetation might recolonize certain areas when resprouting of $P$. juliflora is suppressed simultaneously. Further, the number of $P$. juliflora seedlings was proportionally lower the higher the invasion rate, indicating that $P$. juliflora might suppress seedling growth through allelopathy and, hence, simulate self-thinning in areas of high presence.

With the loss of indigenous grasses and other plant species, the main fodder resource for grazers such as cattle, the number and productivity of animals has reduced substantially (Hamedu 2014). Yosef et al. (2013) using data from the Central Statistical Agency (CSA) of Ethiopia demonstrated that cattle and camel populations in the Amibara zone, which was the study area, declined at a rate of 36\% and 20\%, respectively, between 1997 and 2011 (see Table 2). Although the population of cattle in almost all other zones is declining, the percentage decline in Amibara is the highest compared to other zones (Yosef et al. 2013). In addition, Amibara is the only zone for which both camel and cattle number are declining and is also the zone which is highly invaded with $P$. juliflora.

Further, socio-economic impacts triggered by the invasion of $P$. juliflora comprised increased health risks due to higher exposure to predators and malaria, constrained access to water points and the emergence of new fatal animal diseases like "Harmaku", resulting from cytotoxins damaging the neurons of the intoxicated animals (Silva et al. 2007).

Nevertheless, $P$. juliflora is only one among several ecological problems. A ranking exercise within kebeles (A Kebele is the smallest administrative unit of Ethiopia similar to a ward) affected by $P$. juliflora revealed that Afar pastoralists perceived the diminishing water volume of the Awash River to be as problematic as the spread of P. juliflora or even worse (Hamedu 2014). Pasiecznik et al. (2001) contend that diminishing water volumes in rivers and water courses can be attributed to $P$. juliflora in areas invaded by Prosopis.

Most pastoralists within Baadu, previously known for their wealth due to large cattle herds, now live under conditions of chronic food insecurity (Rettberg 2010). The number of livestock is declining as households are selling off animals to buy food, and about $64 \%$ of the rural Afar households are consuming three or fewer food groups out of seven. In Ethiopia, Afar State has the households with the highest food expenditure and malnutrition as well as the lowest household cereal stock per capita (1 kg/person) at any given time (WFP 2009; CSA 2014). To cope with this food insecurity challenge, there has been a significant diversification of pastoralist

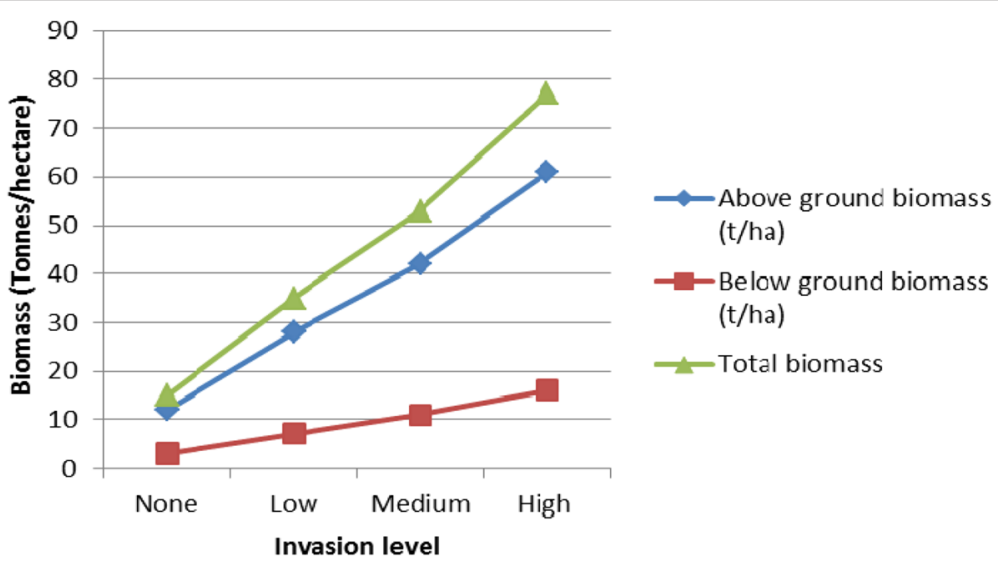

Figure 1 Above and below ground and total biomass of Prosopis juliflora-invaded sites across the different infestation categories as quantified through destructive harvesting 
Table 1 Number of individuals per species for all woody plants recorded in the sample quadrants across the different Prosopis juliflora encroachment sites

\begin{tabular}{llllll}
\hline Site & Species & High & Medium & Low & None \\
\hline Amibara & Acacia mellifera & 0 & 9 & 25 & 0 \\
& Acacia senegal & 0 & 0 & 0 & 928 \\
& Dobera glabra & 50 & 22 & 3 & 0 \\
& Prosopis juliflora & 4200 & 503 & 325 & 44 \\
& Total & 4250 & 534 & 353 & 972 \\
Gewane & Acacia mellifera & 0 & 0 & 0 & 13 \\
& Acacia senegal & 0 & 0 & 0 & 863 \\
& Acacia seyal & 0 & 0 & 25 & 0 \\
& Acacia spp. & 0 & 0 & 50 & 0 \\
& Acacia tortilis & 0 & 0 & 0 & 13 \\
& Balanites aegyptiaca & 0 & 0 & 13 & 0 \\
& Dobera glabra & 0 & 0 & 0 & 12 \\
& Prosopis juliflora & 3850 & 1775 & 1513 & 13 \\
& Total & 3850 & 1775 & 1600 & 913 \\
\hline
\end{tabular}

livelihood strategies and engagement into non-pastoral economic activities. More and more pastoralists became sedentary within the last 20 years, performing different kinds of income-generating activities (wage labour, petty trading and sale of charcoal, firewood, grass mats, etc.) and small-scale irrigation agriculture (Rettberg 2010; Müller-Mahn and Rettberg 2012). Still, in most sedentary households, there are some boys and men who keep on moving with the remaining livestock and livestock is still the main food security asset.

\section{Social and economic impacts of $P$. juliflora}

Socio-economic data was collected from a survey of 490 pastoral households including 213 from Amibara, 177 from Gewane and 100 from Awash Fentale. The total economic value approach was used, and the valuation techniques applied are a combination of stated and revealed preference methods. Since the impacts of $P$. juliflora are both tangible and intangible, combining revealed and stated preference methods ensures that measurements of prices are drawn from the actual financial setting and welfare measurements are less prone to bias (Adamowicz et al. 1994, 1997; Earnhart 2001). In using stated preference techniques, households were asked to subjectively state the quantities and the value of environmental goods generated from Prosopis as shown below. In addition, pastoralists were asked to state the number of animals affected in the previous year, number of animals that died or were slaughtered, and to estimate the loss in weight as well as milk production that they attributed to the invasion of $P$. juliflora. This information was collected for each of six categories of livestock. For products that are traded in the market like milk and meat weights, the revealed preference method was used.

Only few Afar people value P. juliflora for its economic potential, considering it to be a "black gold" due to its monetary benefits through charcoal production and trade (Datona 2014). The results in Table 3 show that the main local use of Prosopis is for fuel wood, house construction and fencing houses and kraals. Very few households are engaged in selling fuel wood or charcoal burning. Also, very few households feed animals with pods and Prosopis leaves. This could explain why most households preferred complete eradication of the Prosopis. On average, $46 \%$ of the environmental income is associated with Prosopis. Only $18 \%$, mainly young and educated Afar households, have been able to generate high profits through charcoal trade but with severe ecological consequences as indigenous trees are similarly (but illegally) cut, which is against the traditional law of the Afar (maada). This law is not respected anymore and the role of customary institutions in natural resource management is increasingly undermined, driven by the desire to diversify livelihoods and income sources in selling wood and charcoal (Datona 2014). There is also serious concern by some interviewed pastoralists that the few powerful people engaged in charcoal making are in favour of the spread of $P$. juliflora and, hence, are acting against encroachment control efforts. The risk of resource-based land conflicts within and among Afar clans and neighbouring ethnic groups in the P. juliflora-affected areas is increasing with the commodification of land through charcoal trade and agriculture (Hamedu 2014).

Results from economic analyses also reveal that the benefits of the P. juliflora invasion in the Afar region are higher than the costs. The total benefits in Ethiopian Birr amounted to about 4.4 billion (231 million USD), and the costs are estimated to be about 2.2 billion ETB (116 million USD). Results also show that if the current invasion level is not controlled, the net present value in

Table 2 The percentage change of cattle and camel in Afar State (Amibara and Mille), Somali region states (Shinile and Jijiga) and Borana zone

\begin{tabular}{|c|c|c|c|c|c|c|c|c|c|c|}
\hline & \multicolumn{10}{|l|}{ Zones } \\
\hline & \multicolumn{2}{|l|}{ Shinile } & \multicolumn{2}{|l|}{ Jijiga } & \multicolumn{2}{|c|}{ Amibara } & \multicolumn{2}{|l|}{ Mille } & \multicolumn{2}{|l|}{ Borena } \\
\hline & Cattle & Camel & Cattle & Camel & Cattle & Camel & Cattle & Camel & Cattle & Camel \\
\hline Percentage change & -14.6 & 16.5 & -8.21 & 241 & -36.2 & -20 & 332 & 1203 & -30.7 & 65.9 \\
\hline
\end{tabular}

Source: Yosef et al. (2013) 
Table 3 Main uses of Prosopis juliflora among Afar pastoral households

\begin{tabular}{|c|c|c|c|c|c|}
\hline Environmental good & Harvests/year & Value/year (ETB) & Proportion due to Prosopis & $\%$ of $\mathrm{HHs}$ benefitting & Prosopis income/hh \\
\hline Fuelwood, home consumption & 119 & 2983 & 65 & 96 & 1939 \\
\hline Fuel wood for sale & 153 & 5648 & 76 & 3 & 4292 \\
\hline Charcoal, home consumption (bags) & 35 & 1712 & 86 & 18 & 1472 \\
\hline Charcoal for sale (bags) & 1043 & 57,631 & 90 & 18 & 51,868 \\
\hline Poles for house construction & 69 & 1664 & 54 & 52 & 899 \\
\hline Poles for house repair & 26 & 210 & 68 & 47 & 143 \\
\hline Fencing (homes farm, kraal) & 34 & 699 & 71 & 74 & 496 \\
\hline Farm implements & 14 & 261 & 43 & 21 & 112 \\
\hline Household furniture & 77 & 1636 & 17 & 4 & 278 \\
\hline Honey (litres) & 48 & 5760 & 5 & 0.2 & 288 \\
\hline Wild fruits & 65 & 530 & 4 & 3 & 21 \\
\hline Bush meat & 12 & 2550 & 23 & 1 & 587 \\
\hline Medicinal use & 49 & 1294 & 6 & 10 & 78 \\
\hline Leaves for livestock feed & 175 & 3995 & 30 & 12 & 1199 \\
\hline Pods for livestock feed & 136 & 3374 & 87 & 39 & 2935 \\
\hline Total & & 95,890 & 46 & & 69,248 \\
\hline
\end{tabular}

Source: Field Survey Data (January 2014 and December 2013): The harvest per year, value per year, proportion and the proportion of households earning a given income are generated from household survey data. Income due to Prosopis is computed from value per year based on proportion income associated to Prosopis

the next 30 years would be negative (37 trillion Birr) (Ilukor et al. 2014). However, the benefits and costs tend to vary between user groups such as mobile pastoralists, sedentary small-scale agro-pastoralists and large-scale farmers (Ayanu et al. 2015). In this study, we found that the benefits to sedentary small-scale agro-pastoralists who participate in wood and charcoal trade as well as to largescale crop farmers are higher than the costs because land is cultivated and the wood is sold. The net present value for households who cut prosopis, sell its wood or charcoal is 516 ETB (27 USD) and for those who cultivate land and also sell wood or charcoal is 7985 ETB (420 USD) per year. Nevertheless, if the invasion is not controlled, the benefits to these user groups would be less than the costs in the near future. For this reason, pastoralists prefer complete eradication and are willing to contribute cash as well as labour to reach this goal relative to non-pastoral households (Tilahun et al. 2014). Our results also revealed that pastoralists are willing to pay 246 ETB (13 USD) and 38 labour days per household in a year to eradicate $P$. juliflora.

However, complete eradication might have significant impacts on the environment in the form of increased wind erosion, evapotranspiration, and sun radiation of opened areas (Haregeweyn et al. 2013). It would further reduce the ability of the Afar environment to sequester carbon as the estimated total $\mathrm{C}$ stock density derived from the $P$. juliflora invasion was about $40 \%$ higher $\left(86 \mathrm{Mg} \mathrm{C} \mathrm{ha}{ }^{-1}\right.$ ) at high than at low $\left(50 \mathrm{Mg} \mathrm{C} \mathrm{ha}{ }^{-1}\right)$ invasion categories $(p<0.05)$. Analyses of existing data about $P$. juliflora invasion generated from a study by Haregeweyn et al.(2013) and climate data acquired from the Amibara weather station reveal that the P. juliflora invasion has been useful in moderating climate variables and reducing expansion of desertification in the Afar region (Ilukor et al. 2014). Increased plant biomass above and below ground as well as higher organic matter content in soils through $P$. juliflora invasion can contribute to capturing $\mathrm{CO}_{2}$ from the atmosphere, which is important for climate change mitigation (Hasen-Yusuf et al. 2013). It further can promote future Carbon trade efforts, which might provide an alternative income generation through payment for environmental services (PES). Moreover, as results from the ecological analyses reveal, the available phosphorus, nitrogen and carbon in the soil were found to be high in highly and intermediate $P$. juliflora-infested sites. Therefore, the soil properties in highly infested sites are suitable for plant growth or crop production once $P$. juliflora has been removed. Based on the soil seed bank study, the ecosystem might recover from $P$. juliflora infestation and native species might return. However, care has to be taken to prevent reinvasion of cleared sites as well as overgrazing as these factors threaten the competitive ability of the native plants in this semi-arid region.

\section{Conclusion and recommendations}

The results of the joint impact assessment presented above suggested that there is need for a participative, institutionalized, locally owned and government-led 
management approach. Although this study tried to capture most aspects of the P. juliflora invasion in the Afar region, some aspects such as increased risk of erosion, the impact of $P$. juliflora on the water table and long-term ecological changes were not examined, making the total economic evaluation incomplete. However, based on our results, we provide the following recommendations for the sustainable management and control of $P$. juliflora in the Afar region.

\section{Securing sustainable land reclamation}

Results from the joint study suggest that total eradication of $P$. juliflora is impossible and not sustainable. The efforts and resources should be directed to clearing of $P$. juliflora in some selected areas with use of the wood for either charcoal or fuel wood and (b) immediate utilization of the cleared land for either pasture or crop farming with the objective of diversifying livelihood strategies. Implementation of this recommendation will require creating innovative ways of involving pastoralists in the mechanical clearing of $P$. juliflora by tapping into local knowledge, local institutions and providing land use rights of the cleared land as well as suitable tools for farming, especially generators for irrigation. Pastoral clans, institutions and locations should be mapped and documented. Each clan should be empowered to oversee the clearing of P. juliflora. The clans should be supported (financially and technically) and community rules should be revised to identify weaknesses and strengths in the management of $P$. juliflora. This support should essentially come from the government and even development partners. In addition, the same clans should also be offered secure rights to use the land for crop or forage production. Secure rights are important because currently the land belongs to the government, and households who were members of the cooperative noted that the land they cleared off $P$. juliflora was given away to the investor. This loss in 'ownership' certainly is one of disincentives to the management of $P$. juliflora in Afar.

\section{Building multi-level institutions}

For any management approach to become effective on the ground, there has to be a strong institutional structure with clear mandates and responsibilities. There should be a clear leadership in the control of $P$. juliflora. One organization at the federal level (preferably the Ministry of Agriculture) should be given the mandate as a lead organization to control the spread of $P$. juliflora (Chekol and Neumann 2014). Under the lead organization, further institutional structures or arrangements should be developed at all administrative levels at the regional level. All these governmental institutional structures will need transparent mandates and sufficient budgets for $P$. juliflora management. Local institutions at the regional and Woreda levels should be linked to customary institutional structures of natural resource management, e.g. through the establishment of joint boards or management committees.

\section{Strengthening local institutions through participation and ownership}

Both local- and national-level institutions and arrangements are needed to ensure sustainable management of $P$. juliflora. The local $P$. juliflora management institutions should be developed in line with the existing local institutions on pasture management and should be recognized by federal and regional governments. In Afar, there are customary leaders called makabantu that are involved in decision-making in matters related to clan grazing lands, relationships with other clans, neighbours and the state and the fiimat $a b b a$ who enforce decisions made by the makabantu of individual clans and the clan leaders from the associated grazing lands ulooto) (see Oba 2012).

These existing local institutional structures should be activated and involved in the management of Prosopis, and this would require documenting existing 'clans' and an examination of their community rules before adapting them to the management of $P$. juliflora. In addition, this process would ensure that $P$. juliflora management institutions are developed participatively by involving communities and their leaders. Participatively developed institutions that are locally owned are the key to sustainable management and control of $P$. juliflora in the Afar region. They will ensure that pastoralist knowledge and views form the basis for control and management of P. juliflora, thus minimizing the tendency of forcing interventions on them. It also minimizes the "free rider problem", the tendency of some pastoralists or households not to participate in $P$. juliflora clearing or management but to benefit from the clearing by others. By providing social sanctions and incentives, pastoralists themselves who are strongly affected by $P$. juliflora invasion would be more actively involved in its management and control other than armed forces that have no incentives. Group-based sanctions or incentives such as clan sanctions or multi-clan sanctions would even be more effective (Reuben 2003).

\section{Focusing on specific $P$. juliflora-invaded areas}

Ecologically, some areas are better suited for P. juliflora eradication than others. Areas with high and dense $P$. juliflora cover might be too difficult and labour/finance consuming. These areas are likely to decline in P. juliflora in the future, anyway, due to self-thinning effects. In contrast, areas that have been invaded rather recently should be cleared selectively and intensely (including root removal). The latter areas are less densely populated with $P$. juliflora and might show the positive effects 
of this species onto the soil nutrient and moisture properties as found in our study. These positive soil characteristics can be used for consecutive planting of native species or cropping fields.

The cleared areas should immediately be restocked with native woody and grassy vegetation to prevent new invasions as abandoned and unused areas are preferred colonization grounds for P. juliflora. Hence, restocked native woody and grassy vegetation or a cropping field, e.g. a dense maize field, will prevent $P$. juliflora from spreading.

Further, the remaining grazing areas should be managed such that no overgrazing effects arise as the latter will encourage $P$. juliflora invasions. The grass layer must be kept intact and should be interspersed with few native trees but $P$. juliflora growing into tree shape can also be allowed.

The spread of $P$. juliflora should be undermined by collecting pods regularly and crushing them before livestock can forage on these plant parts as livestock have been shown to be an important dispersal vector. Alternatively, livestock faeces could be collected in the course of a day and used as fuel for fires, once dried, or as manure for crop fields in the near surroundings, after $P$. juliflora pods have been removed.

\section{Flexibility of management interventions}

$P$. juliflora control or management interventions should be context-specific, culturally sensitive and should account for the interest of both mobile pastoralism and agro-pastoralism. Clans currently affected by the P. juliflora invasion in proximity to the Awash River combine different livelihood strategies, including mobile pastoralism, settled small-scale agriculture and charcoal production. The reclamation and future use of land has to take note of this diversity, which should be supported. In addition, there is need to improve the provision of animal and human health care services in the Afar region to be able to handle new animal diseases like Harmaku and increase $\mathrm{d}$ incidence in malaria.

\section{Strengthening regional cooperation and learning}

In addition to local and national institutions, there is a need for regional policies and institutions to facilitate efforts to control and manage the negative impacts of $P$. juliflora and optimize the positive impacts of this species through sharing knowledge, advocacy and research. IGAD is an Eastern Africa organization created in 1996 to replace the Intergovernmental Authority on Drought and Development (IGADD) which was founded in 1986. The organization was to help member states Djibouti, Ethiopia, Kenya, Somalia, Sudan and Uganda to cope up with the recurring and severe droughts and other natural disasters between 1974 and 1984 which caused widespread famine, ecological degradation and economic hardship in the Eastern Africa region (AU 1996). The establishment of the regional institutions and policies should be spearheaded by the Intergovernmental Authority on Development (IGAD).

\section{Encouraging further research}

There is a need to invest in P. juliflora research in Afar in order to develop innovative ways of controlling this species but also assessing the impact of $P$. juliflora invasion in the Afar region of Ethiopia. Particular areas of research that need to be addressed are the following:

(a) The feasibility of biological control agents using experiences from other countries.

(b)The relationship between spreading patterns and hydrological conditions.

(c) The role of $P$. juliflora in desalinization and crop production.

(d)An in-depth institutional analysis to highlight why the existing $P$. juliflora management strategy for Ethiopia has not been implemented so far and what institutional arrangements will work for Prosopis management in Afar.

(e) Research on innovative uses of $P$. juliflora that are socially acceptable and suited to the Afar region and people, for example, on the possible use of $P$. juliflora pods as a source of human nutritious foods, medicinal uses and as the basis of livelihood diversification, based on the experience from other countries.

Authors' contributions

II was leading the development of the synthesis and the economic analysis, SR was in charge of synthesizing the social analysis and ACT was in charge of synthesizing the ecological analysis. RB was the project head, and critically reviewed the results and recommendations. All authors read and approved the final manuscript.

\section{Authors' information}

$\mathrm{II}$ is a lecturer at Makerere University and Research Associate consultant for FAO based at International Institute of Tropical Agriculture, Malawi. His research interest is on application of New Institutional Economics to analyse food security, service delivery and environmental challenges in developing countries. SR is a social scientist whose research interest is in Geographical Development Studies in Africa.

AT is an agroecologist and scientific assistant at Agro-ecology in the Tropics and Subtropics, University of Hohenheim, Germany. RB is the Chair of 'Social and Institutional Change in Agricultural Development' at the University of Hohenheim, Germany, and one of her research interests is on how rural services, including livestock services, can be delivered more effectively to rural poor/marginalized people.

\section{Competing interests}

The authors declare that they have no competing interests.

Received: 10 October 2015 Accepted: 4 July 2016

Published online: 19 August 2016

References

Adamowicz, W., J. Louviere, and M. Williams. 1994. Combining revealed and stated preference methods for valuing environmental amenities. Journal of Environmental Economics and Management 26: 271-292. doi:10.1006/jeem.1994.1017. 
Adamowicz, W., Joffre Swait, Peter Boxall, Jordan Louviere, and Michael Williams. 1997. Perceptions vs objective measures of environmental quality in combined revealed-stated preference models of environmental valuation. Journal of Environmental and Management 32: 65-84.

Admasu, D. 2008. Invasive plants and food security: The case of Prosopis juliflora in the Afar region of Ethiopia, 1-13. FARM-Africa, IUCN.

ANRS. 2010. Afar National Regional State Programme of Plan on Adaptation to Climate Change. Environmental Protection Authority (EPA) of the Federal Democratic Republic of Ethiopia.

AU. 1996. Intergovernmental Authority for Development (IGAD). http://au.int/en/ recs/igad.

Ayanu, Yohannes, Anke Jentsch, and Detlef Müller-Mahn. 2015. Ecosystem engineer unleashed: Prosopis juliflora threatening ecosystem services? Regional Environmental Change 15: 155-167. doi:10.1007/s10113-014-0616-x.

Berhanu, Abiyot, and Getachew Tesfaye. 2006. The Prosopis dilemma, impacts on dryland biodiversity and some controlling methods. Journal of the Drylands 1: 158-164

Bhojvaid, P.P., and V.R. Timmer. 1998. Soil dynamics in an age sequence of Prosopis juliflora planted for sodic soil restoration in India. Forest Ecology and Management 106: 181-193. doi:10.1016/S0378-1127(97)00310-1.

Chaturvedi, Om Hari, and Artabandhu Sahoo. 2013. Nutrient utilization and rumen metabolism in sheep fed Prosopis juliflora pods and Cenchrus grass. Springerplus 2: 598. doi:10.1186/2193-1801-2-598.

Chekol, Wondimagegne, and Irmfried Neumann. 2014. Prosopis juliflora, Parthenium and beyond, challenges for an integrated strategy of IAS control in the Afar Region. In Managing Prosopis Juliflora for better (agro-) pastoral Livelihoods in the Horn of Africa.

Choge, S.K., N.M. Pasiecznik, M. Harvey, J. Wright, S.Z. Awan, and P.J.C. Harris 2007. Prosopis pods as human food, with special reference to Kenya. In Water SA 33: 419-424. doi:10.4314/wsa.v33i3.49162.

CSA. 2014. Ethiopia comprehensive food security and vulnerability analysis. Addis Ababa.

Datona, Mohammed. 2014. Socio-economic impacts of Prosopis juliflora-related charcoal trade in Gewane Woreda, Afar Region. In Managing Prosopis Juliflora for better (agro -) pastoral Livelihoods in the Horn of Africa.

Earnhart, Dietrich. 2001. Combining revealed and stated preference methods to value environmental amenities at residential locations. Land Economics 77: 12-29. doi:http://le.uwpress.org/content/77/1/12.full.pdf+html.

Hamedu, Herrie. 2014. Socioeconomic and ecological impacts of Prosopis juliflora invasion in Gewane and Buremudaytu Woredas of the Afar region. In Regional conference on managing Prosopis juliflora for better (agro-)pastoral livelihoods in the Horn of Africa, 118-124. Addis Ababa, Ethiopia: Desalegn Hotel.

Haregeweyn, N., A. Tsunekawa, M. Tsubo, D. Meshesha, and A. Melkie. 2013. Analysis of the invasion rate, impacts and control measures of Prosopis juliflora: A case study of Amibara District, Eastern Ethiopia. Environmental Monitoring and Assessment 185: 7527-42. doi:10.1007/s10661-013-3117-3.

Hasen-Yusuf, M., A.C. Treydte, E. Abule, and J. Sauerborn. 2013. Predicting aboveground biomass of woody encroacher species in semi-arid rangelands, Ethiopia. Journal of Arid Environments 96: 64-72.

llukor, John, Regina Birner, Mesfin Tilahun, and Shimelis Getu. 2014. A socialeconomic assessment of the impact of Prosopis juliflora invasion and participative management approaches in the Afar Region, Ethiopia. In Managing Prosopis Juliflora for better (agro-) pastoral Livelihoods in the Horn of Africa Proceedings of the Regional Conference May 1 - May 2,2014, Addis Ababa, Ethiopia

Kahi, C.H., R.K. Ngugi, S.M. Mureithi, and J.C. Ng'ethe. 2009. The canopy effects of Prosopis juliflora (dc.) and Acacia tortilis (hayne) trees on herbaceous plants species and soil physico-chemical properties in Njemps flats, Kenya. Tropical and Subtropical Agroecosystems 1: 117-122.

Mahgoub, Osman, Isam T. Kadim, Neil E. Forsberg, Dawood S. Al-Ajmi, Naseeb M. Al-Sagry, Abdullah S. Al-Abri, and Kanthi Annamalai. 2005. Evaluation of Meskit (Prosopis juliflora) pods as a feed for goats. Animal Feed Science and Technology 121: 319-327. doi:10.1016/j.anifeedsci.2005.01.016.

Mehari, Zeraye H. 2015. The invasion of Prosopis juliflora and Afar pastoral livelihoods in the Middle Awash area of Ethiopia. Ecological Processes 4. Ecological Processes: 1-13. doi:10.1186/s13717-015-0039-8.

MoARD. 2005. National biodiversity strategy and action plan. Addis Ababa: Government of the federal democratic republic of Ethiopia.
Müller-Mahn, D., and S. Rettberg. 2012. Human-environment interactions: the invasion of Prosopis juliflora in the drylands of northeast Ethiopia. Cambridge: Changing deserts Whitehorse Press.

Mwangi, Esther, and Brent Swallow. 2008. Prosopis juliflora invasion and rural livelihoods in the Lake Baringo area of Kenya. Conservation and Society 6: 130-140.

Oba, Gufu. 2012. Harnessing pastoralists' indigenous knowledge for rangeland management: Three African case studies. Pastoralism: Research, Policy and Practice 2: 1. doi:10.1186/2041-7136-2-1.

Pasiecznik, P Felker, PJC Harris, LN Harsh, JC Tewari, G Cruz, K Cadoret, and LJ Maldonado. 2001. The Prosopis juliflora - Prosopis pallida complex: A monograph.

Rettberg, Simone. 2010. Contested narratives of pastoral vulnerability and risk in Ethiopia's Afar region 1. doi:10.3362/2041-7136.2010.014.

Reuben, Ernesto. 2003. The evolution of theories of collective action. Amsterdan: Universidad de Amsterdam.

Ryan, Faith. 2011. US Forest Service Technical Assistance Trip to Ethiopia: Invasive species management. Report Submitted to USAID.

Sawal, R. K., Ram Ratan, and S. B S Yadav. 2004. Mesquite (Prosopis juliflora) pods as a feed resource for livestock - a review. Asian-Australasian Journal of Animal Sciences.

Silva, A.M., A.R. Silva, A.M. Pinheiro, S.R. Freitas, V.D. Silva, C.S. Souza, J.B. Hughes, et al. 2007. Alkaloids from Prosopis juliflora leaves induce glial activation, cytotoxicity and stimulate NO production. Toxicon 49: 601-14. doi:10.1016/j.toxicon.2006.07.037.

Stein, R B D, L R a de Toledo, F Q de Almeida, a C Arnaut, L T Patitucci, J S Neto, and V T M da Costa. 2005. Effects of feeding mesquite pod meal (Prosopis juliflora (Swartz) DC) for horses. Revista Brasileira De Zootecnia-Brazilian Journal of Animal Science 34:1240-1247.

Tilahun, Mesfin, Regina Birner, and John Ilukor. 2014. Households' demand for mitigation of Prosopis juliflora invasion in the Afar Region of Ethiopia: A contingent valuation. In Managing Prosopis Juliflora for better (agro-) pastoral Livelihoods in the Horn of Africa Proceedings of the Regional Conference May 1 - May 2, 2014, Addis Ababa, Ethiopia.

Treydte, Anna C., Emiru Birhane, and Abeje Eshete. 2014. Ecological challenges and potential carbon storage benefits of Prosopis juliflora in Afar. In Managing Prosopis Juliflora for better (agro-) pastoral Livelihoods in the Horn of Africa Proceedings of the Regional Conference May 1 - May 2, 2014, Addis Ababa, Ethiopia.

WFP. 2009. Food security and vulnerability in selected towns of Afar and Amhara Regions, Ethiopia: WFP-Ethiopia Vulnerability Assessment and Mapping (VAM). Addis Ababa, Ethiopia.

Yosef, T., U. Mengistu, A. Solomon, Y.K. Mohammed, and K. Kefelegn. 2013. Camel and cattle population dynamics and livelihood diversification as a response to climate change in pastoral areas of Ethiopia. Livestock Research for Rural Development 25: 1-10.

\section{Submit your manuscript to a SpringerOpen ${ }^{\circ}$ journal and benefit from:}

- Convenient online submission

- Rigorous peer review

- Immediate publication on acceptance

- Open access: articles freely available online

- High visibility within the field

- Retaining the copyright to your article

Submit your next manuscript at $>$ springeropen.com 